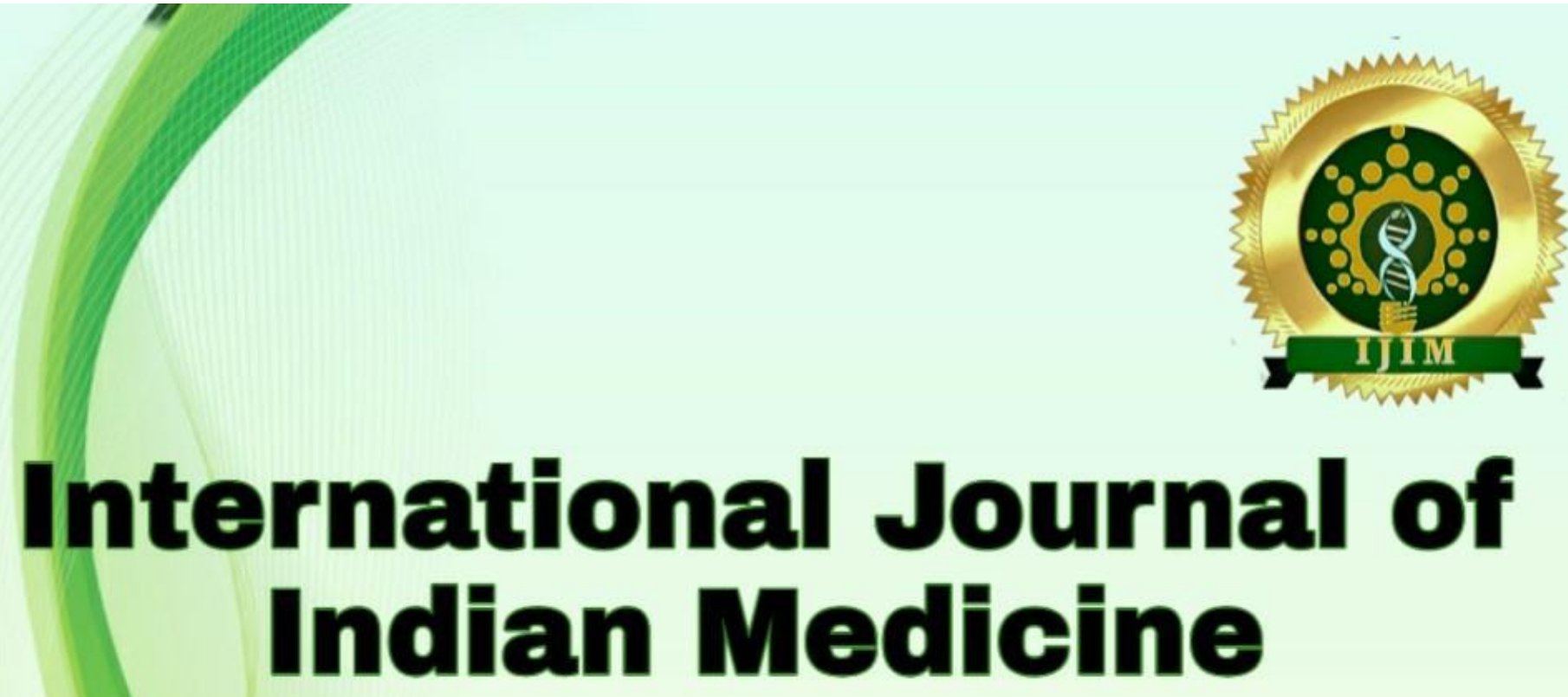




\section{International Journal of Indian Medicine}

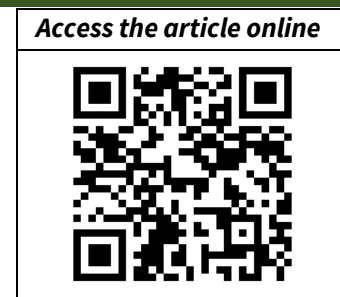

International Category Code (ICC): ||||||||||||||| ICC-1702 International Journal Address (IJA): |||||||||||||||||||||||||||| |JA.ZONE/258276217634

\section{Ayurveda Aspects on Vitiligo and its Management through Classical Approaches of Ayurveda \\ Gupta S $^{1}$, Gupta M. ${ }^{2}$}

1. Professor, Dept of Kayachikitsa, Jupiter Ayurveda Medical College, Nagpur.

2. Professor, Dept of Kriyashareer, Bhausaheb Mulak Ayurved College \& Hospital, Buttibori, Nagpur.

\section{Abstract:}

Two types of Kushta are described in Ayurveda classics, Mahakushta and Kshudrakushta. Further Mahakushta is subdivided into 7 and Kshudrakushta into 11 types. Shwitra is disease manifested through skin can be co-related with Vitiligo (leukoderma), is a pigmentation disorder with complex causes and as per modern aspect. Imbalance of Vata and Bhrajaka pitta resides in skin mainly leads skin disease including vitiligo which possess symptom of Twak vaivarnyata. Switra also described as Shwetakushta and categorizes as Kushta rogas, which mainly involves vitiation of Doshas along with disturbance of Rakta, Mamsa and Medhas Dhatus. Ayurveda described several ways to treat vitiligo including utilization of Shodhana karma and herbal medicines. Various types of Lepa, Ghrita, Avaleha, Tail , Asava-Arista and Vati are mentioned in Ayurveda texts to treat Shwitra. Present article described Ayurveda perspectives on vitiligo and its management through ancient approaches.

Keywords: Vitiligo, Shwitra, Rakta, Mamsa, Lepa, Ghrita

\section{Corresponding Author: \\ Dr.Sangeeta Jain Gupta}

Professor, Dept of Kayachikitsa,

Jupiter Ayurveda Medical College, Nagpur.

Email: drsangeetajaingupta@gmail.com Mobile no. : 9325847733

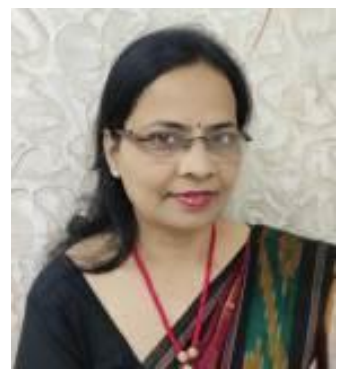




\section{INTRODUCTION:}

Two types of Kushta are described in Ayurveda classics, Mahakushta and Kshudrakushta. Further Mahakushta is subdivided into 7 and Kshudrakushta into 11 types[1] and total 18 types of Kushthas described in Chikitsasthana.[2]

Vitiligo is disease of skin which described as Shwitra in Ayurveda and involves improper distribution of melanin beneath the skin surface. Hereditary, environmental factor, medicines, drug abuse, side effects of radiation or chemotherapy, etc., are major causes of skin diseases. Viruddhahara, Chardivegadharana, Atibhojana, Atyamla, int ake of Lavana, Madhura and Katu Rasa Ahara, Matsyabhakshana and Papakarma, etc. are major causes of vitiligo $[3,5]$.

Ayurveda described three types of Switra as described in Figure 1, Daruna is condition in which Doshas vitiates Rakta dhatu and red color patches will appear on skin. Aruna is another type of Switra in which Doshas vitiates Mamsa dhatu and coppery color patches occurs on skin while Kilasa is condition of Switra in which Medho dhatu get vitiates with Doshas and white color patches occurs on skin.[6]

Ayurveda advocates various therapeutic options for treating Switra like; Shodana chikitsa (Vamana, Virechana and Rakta mokshana), Shamana Chikitsa (oral and external medications) and strict dietary restrictions along with lifestyle modifications and Yoga [7].

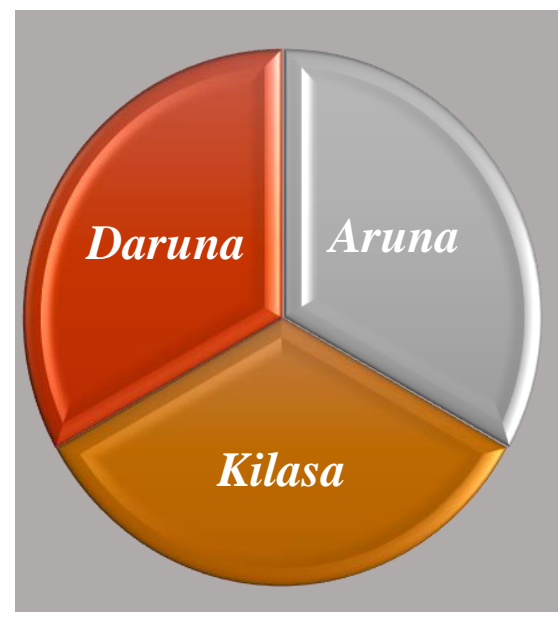

Figure 1: Various types of Shwitra Modern science described vitiligo as condition of de-pigmentation of skin which not only causes physical distress but also leads psychological distress and social isolation. The disease involves gradual loss of pigment (melanin) from the dermal layers and appearance of white patches. Area of hands, neck, back and wrists are mainly affected by such types of condition. White or pale colored patch small in size mainly appears on skin and enlarges in due course of time. Small areas of body such as lips, face, scalp, legs, palms, soles and fingers, etc. also get affected [8]. Ayurveda described 
involvement of three Doshas; Vata, Pitta and Kapha doshas in vitiligo as follows:

- Vataja shwitra posses Ruksha and redblack color patches.

- Pittaja shwitra possess coppery or lotus-like color along with symptoms of Daha and loss of hair.

- Kaphaja shwitra possess hard and white color patches with symptom of itching.

As mentioned above disturbance of Rakta, Mansa and Meda Dhatus mainly associated with vitiation of Vaata, Pitta and Kapha Dosha in vitiligo. $[9,10]$

\section{Samprapti:}

The process with the vitiation of Doshas, due to specific Nidana and which lead to the fullfledged manifestation of the disease after the Dosha- Dushya Sammurchana is called Samprapti. Its very essential and useful for the physician to understand the specific features of a disease, with a special reference to Dosha, Agni etc.[11]

Etiological factors affect Doshas; Vata, Pitta and Kapha which aggravates in skin, Rakta and Mamsa. Involvement of Rasa and Raktha leads major symptoms of vitiligo. As per severity of disease it is believed that Vataja Shwitra is difficult to cure while Pittaja Shwitra is more difficult to treat and Kaphaja Shwitra is considered impossible to treat. [12]

Chikitsa:[13,14,15,16]

Shodhana karma suggested as purification measure to eliminate morbid Dosha along with herbal medications. Oil massage and local application of herbal Lepa provides symptomatic relief. Kwatha of Malayu, Asana, Priyangu, Satapuspa and Ambhasa advocated for curing disease pathogenesis. Ankollakadi, Avalgujadi, Bakucyadi, Balyadi, Bhallatakadi, Bhringarajadi, Gandhakadi, Gu njaGunjaphaladi, Manasiladi, Marichadi, Path yadi Lepa,Putikadi Lepa,Patrakadi Lepa, Triphaladi Lepa and Talakadi Lepa, etc. advised for therapeutic action in vitiligo. Similarly compounds formulations such as Bakuchi prayoga, Bhadrodumbarikadi yoga,Bakuchi bija yoga, Kakodumbarika kasaya, Dhatryadi kwata and Khadiradi Kashayam, etc. prescribed for relieving disease manifestation.

\section{Churna for Vitiligo:}

- Bakucyadya Curna,

- Khadira saradi Curna

- Pancanimba Curna.

\section{Herbalized Ghee for Vitiligo:}

- Jatyadi Ghrita 
- Mahamarkara Ghrita

- Mahaneela Ghrita

- Neelaka Ghrita

- Somaraji Ghrita

Herbalized oil (Taila):

- Aragwadhayadya Tail

- Chitrakadya Tail

- Jyotishmati Tail

- Kusta Kalanala Tail

- Laghu maricadya Tail

- Manasiladya Tail

- Visha Tail

\section{Vati for Vitiligo:}

- Swayambhu Guggulu

- Brhat Swayambhuva Guggulu

- Triphala Gutika

\section{Rasousadha for Vitiligo:}

- Galitakustari Rasa

- Khageswara Rasa

- Kustebhakesari Rasa

- Medani Sara Rasa

- Tarakeswara Rasa

- Vijayeswara Rasa

Pathya (wholesome diet and habits) for Vitiligo:[17]

- Vrata-pooja-patha-dana

- Puranashali

- Godhuma and Mudga

- Patola and Kadirodaka, etc.
Apathya (unwholesome food and habits) for Vitiligo:[18]

- Viruddhahara and Guru ahara

- Vidahiahara

- Vishtambhiahara

- Kanda-Moola

- Amla-katu-lavanarasa

- Kritaghnata

Snana: Siddharthakasnana, Triphala Siddhajala, Dhavadigomutraparișeka etc. DISCUSSION:

Shwitra is skin disease can be correlated with vitiligo as per the theory of modern science. It is a depigmenting skin disorder that causes regions of skin to lose colour. Vitiation of Doshas, Rakta, Mamsa and Medhas Dhatus mainly involves in disease pathogenesis. Improper distribution of melanin beneath the skin surface produces patches over the skin. Viruddhahara,

Atibhojana, Atyamla, Chardivegadharana, intake of Lavana, Madhura and Katu Rasa Ahara and Papakarma, etc. are considered as triggering factors of disease. It affects persons of various ages, ethnic groups, and skin types, accounting for around 0.5 percent to $1 \%$ of the global population. Tridoshas vitiation occurs in connection with Twakchagat Pitta Dosha and Rasa-Rakta-mamasa -Udaka 
Dhatu due to Atisevan of Asamyak Aahar Vihar. Shwitra-Kushtha, or Vitiligo, is the outcome of extensive vitiation at the Rasa and Rakta levels. Vata Pradhan Shwitra is difficult to treat, Pitta Pradhan Shwitra is much more difficult to treat, and Kapha Pradhan Shwitra is incurable. Lesions on the palm, sole, genitalia, and lips are also incurable. However, lesions caused by burns that are non-matted, recently formed, thin, and have black hair are treatable. Ayurveda described several ways to treat vitiligo including Shodhana and Shamhana therapies. Virechana is the greatest Shodhana Karma according to Dosha-Dushya for relieving Aam. Virechan with Psoralia Corylifolia (Bakuchi) and Euphobia Neriifolia herbal decoction (Snuhi). Bakuchyadi Churna, Khadirasaradi Churna, etc. can be utilised for Shamana therapy. Throughout the days of treatment patient should follow Pathyakar Aahar-Vihaar and Yoga practices.

\section{CONCLUSION:}

Ayurveda described different approach for the treatment of Vitiligo including purification measures i.e., Shodhan Chikitsa is utmost essential alongwith Kusthahar medicines. Ayurveda described several internal medicines as well as topical drugs for reliving symptoms of vitiligo. Various types of Lepa, Ghrita, Avaleha, Tail , Asava-Arista and Vati are mentioned in Ayurveda to treat vitiligo (Shwitra) this treatment ultimately reduce the comorbidity among the patient living with the condition like Vitiligo.

\section{REFERENCES:}

1. Agnivesha, Charaka, Dridhbala, Charak Samhita, Nidansthana, 5/5, Hindi Vidyotini Commentary by Pt. Kashinath Shastri and Dr. Gorakhnath Chaturvedi, Part 1,Reprint. : Chaukhamba Bharti Academy,Varanasi;2001.p.643.

2. Agnivesha, Charaka, Dridhbala, Charak Samhita,Chikitsasthana,7/13,Hindi

Vidyotini Commentary by Pt.Kashinath Shastri and Dr. Gorakhnath Chaturvedi,Part 1,Reprint. : Chaukhamba Bharti Academy,Varanasi;2002.p.250

3. Agnivesh, Charaka, Dridhabala (1993) Charaksamhita. Chaukhambha Bharati Academy, Varanasi chikitsathana 7: 162177.

4. Madhavkar (1994) Madhavnidana. Chaukhambha Sanskrit Sansthan, Varanasi Kushthanidanam 39: 164. 
5. Ranade S, Deshapande AP, Jawalagekar RR (1996) Dravyagunavigyan. Anmol Prakashan, Pune 34: 444.

6. Prasad PV, Bhatnagar VK (2003) MedicoHistorical Study of "Kilasa" (Vitiligo /leucoderma) a common skin disorder. Bull Indian Inst Hist Med Hyderabad 33: 113-127.

7. Bhavamishra. Bhavaprakasha, Kustachikitsitadhyaya. India, Varanasi: Chowkhamba Orientalia; 2010. p. 211.

8. Khushboo PS, Jadhav VM, Kadam VJ, Sathe NS. Psoralea corylifolia Linn."Kushtanashini". Pharmacogn Rev 2010;4:69-76.

9. Susruta, Sushruta Samhita with commentary of Dalhana, by Vaidya Jadava JI Trikamji Acarya, Chaukhambha Orientalia; Varanasi. 7th ed. Sutra Sthana 45/194, 2002, p. 211.

10. Vagbhata. Astanga Samgraham Kusta Krimi Nidana Adhyaya. Varanasi, India: Chowkhamba Krishnadas Academy; 2005. p. 39.

11. Bhel Samhita, Nidan sthana, text with English translation commentary and critical notes by Dr.K.H.Krishnaurthy, edited by Prof. Priyavrat Sharma Reprint : Chaukhamba Visvabharti, Varanasi; 2008
12. Agnivesha, Charaka, Dridhbala, Charak Samhita, Chikitsasthana, 7/9-10, Hindi Vidyotini Commentary by Pt. KashinathShastri and Dr. Gorakhnath Chaturvedi, Part 1,Reprint. : Chaukhamba Bharti Academy, Varanasi; 2002.p.248.

13. Shukla V, editor,(2nd ed.).Charaka Samhita of Charak, Chikitstasthan: Chapter 7, Verse 39-40. Varanasi:Chowkhambha Sanskrit Series, 2002;186

14. Prof. K.R. Srikantha Murthy editor. 1st ed, Susruta Samhita, Chikitsa sthana, Chapter 9, Verse 43. Vol-II. Varanasi: Chaukhamba Orientalia, 2001;pg436.

15. Prof. Ramanath Dwivedy, editor, Chakradatta- of Shri Chakrapanidatta, with 'Vaidataprabha 'Hindi Commentary and notes by Dr. Indradeva Tripathi, 4 th ed, Chapter 50-Kushtha Chikitsa, Varanasi: Chaukhambha Sanskrit Series; 2002. p. 279.

16. Tripathi B, editor, (1st ed.). Ashtanga Hridaya of Vagbhata, Chikitsa Sthana; Chapter 19, Verse 98. Varanasi: Chowkhambha Sanskrit Series, 2009; 528. 17. Sharma RK and Bhagwan Dash. editor, (2nd ed.). Charaka Samhita, Sutra Sthana, Chapter 25, Verse 45, English Translation, 
Reprint. Vol. 4. Varanasi: Chowkhamba

Sanskrit Series Office; 2009. pp. 244

18. Shukla V, editor,(2nd ed.). Charaka

Samhita of Charak, Chikitstasthan:

Source of Support : None declared

Conflict of interest : Nil

(C) 2022 IJIM (International Journal of Indian Medicine) | An Official Publication of Ayurveda Research \& Career Academy.(ARCA) www.ijim.co.in Email: ijimjournal1@gmail.com 